\title{
Introducing the Civil Wars Mediation (CWM) dataset
}

\author{
Karl DeRouen Jr \\ Department of Political Science, University of Alabama \\ Jacob Bercovitch ${ }^{*}$ \\ Department of Political Science, University of Canterbury \\ Paulina Pospieszna \\ Department of Politics and Management, University of Konstanz
}

\begin{abstract}
Mediation is one of the few mechanisms the international community can deploy that will affect civil wars. This article introduces the dataset on mediation in civil wars - termed the Civil War Mediation (CWM) dataset. This is the first dataset to focus solely on civil war mediation. These data contribute to the present state of quantitative research on mediation in three important respects: the data are collected for the period of 1946-2004, are organized by mediation cases and by civil war episode, and provide detailed information about mediation incidences. The article first presents a few variables included in the dataset that are motivated by theoretical arguments from the literature. After a presentation of summary statistics, attention is turned to using the CWM data to explore the determinants of mediation. Mediation is shown to be a function of war type (territorial and internationalized wars are more likely to be mediated), war duration (the longer the war the higher the probability of mediation), supply-side factors (the number of democracies in the world and the global polity average), and stratum (subsequent wars are less likely to be mediated). Battle-related deaths also seem to increase the chances of mediation, though the relationship is only weakly significant. The article concludes with suggestions for future research that can benefit from the dataset.
\end{abstract}

\section{Keywords}

civil war, dataset, mediation

\section{Introduction}

Mediation is one of the few mechanisms the international community can deploy that will make a change to civil wars. Therefore, we set out to develop a unique dataset of third-party mediation in civil wars. Until now, there has not been a dataset that focuses solely on civil war mediation. This article presents new data on mediation in internal conflicts for the period $1946-2004 .{ }^{1}$ The Civil War Mediation (CWM) dataset documents approximately 460 mediation events.

The first section of the article explains the need for a new dataset. Then, specifics related to the dataset are presented. The next section consists of a statistical analysis of the determinants of mediation. The findings confirm and challenge existing studies. We conclude that the CWM data open new avenues for the study of mediation in civil wars.

\section{Why a new dataset?}

Within the community of civil war researchers there is growing interest in mediation as a promising avenue for dealing with or terminating civil wars. However, civil

\footnotetext{
* We regret to say that Jacob Bercovitch passed away on 10 June 2011, after the article had been accepted for publication.

${ }^{1}$ We are currently extending the dataset beyond 2004.

Corresponding author:

kderouen@bama.ua.edu
} 
war mediation research lags somewhat behind similar work in the interstate literature where for several years scholars (see e.g. Beardsley, 2010; Gartner \& Bercovitch, 2006; Greig, 2005; Wilkenfeld et al., 2003) have done compelling work using Bercovitch's International Conflict Management (ICM) data (1999) and Wilkenfeld et al.'s (2003) International Crisis Behavior (ICB) mediation data among others. The absence of a civil war mediation specific dataset has hampered our efforts to develop a better understanding of how to terminate and manage civil wars.

The CWM dataset is the first to focus solely on civil war mediation. The ICB dataset focuses on international crises and the ICM dataset focuses on civil and interstate wars. A new dataset by Regan, Frank \& Aydin (2009) provides a valuable new contribution on diplomatic interventions in civil war but they treat mediation as only one aspect of non-military interventions, and they omit smaller civil wars with a fatality threshold below 200. Beber (2010), Eralp et al. (2010), and Svensson (2007) have also generated useful civil war mediation datasets, but their coverage is presently limited to the post-Cold War era. Each of the datasets mentioned here is useful in its own way and will be used to answer different questions.

We use general conflict variables from the UCDP Conflict Termination dataset such as war type, location, territory, episode start and end dates, types of termination, and name of rebel group. To this the CWM data adds information on mediation incidences, such as year of mediation event, mediation start and end dates, and variables that describe mediation efforts - the identity of mediators, mediation strategy, number of previous mediation attempts, and mediation outcome after two and five years.

The CWM dataset will contribute to research on mediation occurrence (see Beardsley, 2010; Greig \& Diehl, 2006), conflict management (see Regan \& Stam, 2000; Rauchhaus, 2006; Regan \& Aydin, 2006; Smith \& Stam, 2003; Wilkenfeld et al., 2005), duration of the peace (see DeRouen, Bercovitch \& Wei, 2009; Beardsley, 2008; Walter, 2002), mediator identity and characteristics (see Crescenzi et al., 2008; Kydd, 2003; Svensson, 2007), and strategy (see Bercovitch \& Gartner, 2006; Touval \& Zartman, 1985).

\section{The CWM dataset}

The CWM dataset is built upon the foundation provided by the UCDP Conflict Termination dataset assembled by Kreutz (2010). The data provided by UCDP are exceptionally nuanced. There are 319 episodes between
1946 and 2004 that meet the UCDP/PRIO definition of civil war:

a contested incompatibility that concerns government or territory where the use of armed force between two parties, of which at least one is the government of a state, results in at least 25 battle-related deaths. $^{2}$

By comparison, Regan's Diplomatic Intervention and Civil War (DICW) data provide information on 68 wars. While casualty counts might be lower in the smaller wars, they can still have devastating economic, health, and displacement ramifications.

The definition of mediation is provided by Bercovitch, Anagnoson \& Wille (1991: 8):

a process of conflict management where disputants seek the assistance of, or accept an offer of help from, an individual, group, or state, or organization to settle their conflict or resolve their differences without resorting to physical force or invoking the authority of law.

In the initial phase of this project we are mainly interested in actual mediations rather than offers or invitations. Various topics could be addressed by the mediator: prisoner releases, peace agreements, amnesty, etc.

\section{Data collection}

In order to identify mediation-related variables in civil war episodes, researchers relied on the cases mentioned in the public sources, specifically Keesing's World News Archive, LexisNexis, The Times (London), and Proquest Historical Papers. Every effort was made to avoid temporal and coder bias. The first step was to cover all of the wars with Keesing's (online) because it provided consistent coverage for all years and from a wide variety of foreign newspapers. After Keesing's, other sources were consulted. The Times (online) was available to 1985. Proquest (online) provided full-text articles from the New York Times (to 2001), Wall Street Journal (to 1988), Washington Post (to 1991), and Atlanta Journal Constitution (to 2003). LexisNexis Academic (online) provided extremely broad coverage from 1980 to 2004 with full-text articles from, among others, general news (e.g. India Today), newspapers (e.g. International Herald Tribune), business (e.g. African Business, Economist) and TV and radio news transcripts

\footnotetext{
${ }^{2}$ UCDP definitions available at http://www.pcr.uu.se/research/ucdp/ definitions/definition_of_armed_conflict/
} 
(e.g. BBC Monitoring Services). After going through these sources a number of times, we drew upon Regan et al. (2009) to identify cases (including identity, strategy and outcome) we missed that corresponded to our list of wars and then identified these cases in Keesing's. The small percentage that could not be located in Keesing's was identified in the other sources listed above. About 110 cases were first identified using Regan et al. (these were probably first missed by our coders because most of these cases reflected successive mediations in the same conflicts). Results from the empirical analysis were roughly the same with or without these additional cases.

Inter-coder reliability was carried out through coders trading cases and back-checking by new coders. Each case was looked at by at least two coders. Approximately 460 separate mediation cases were identified using the temporal sequencing in Figure 1. Mediations are matched to a war if the mediation took place during the active war spell or in the subsequent peace as indicated in the figure. Wars are terminated through inactivity, military victory, or negotiated settlement (see Kreutz,
2010). The next sections provide more detailed information on some CWM variables.

\section{Identifying mediators}

Figure 2 identifies the leading mediators. The top categories confirm findings of others (e.g. Crescenzi et al., 2008; Regan, Frank \& Aydin, 2009). The UN is the leading entity engaged in mediation ( $32 \%$ of all cases mediated by organizations). Other popular IGO mediators are: the Intergovernmental Authority on Development, the European Union, and the Organization of African Unity.

\section{Mediation strategy}

An important part of this project is to identify strategies used by mediators. The CWM data presented rely on Bercovitch \& DeRouen's (2004) definitions of strategies based on the assertiveness of the mediator. The distribution of the strategies is: Communicative/Facilitative (39\%), Procedural (53\%), and Directive (8\%). Mediators are most likely to employ more passive roles

Mediation Range I

Mediation Range II

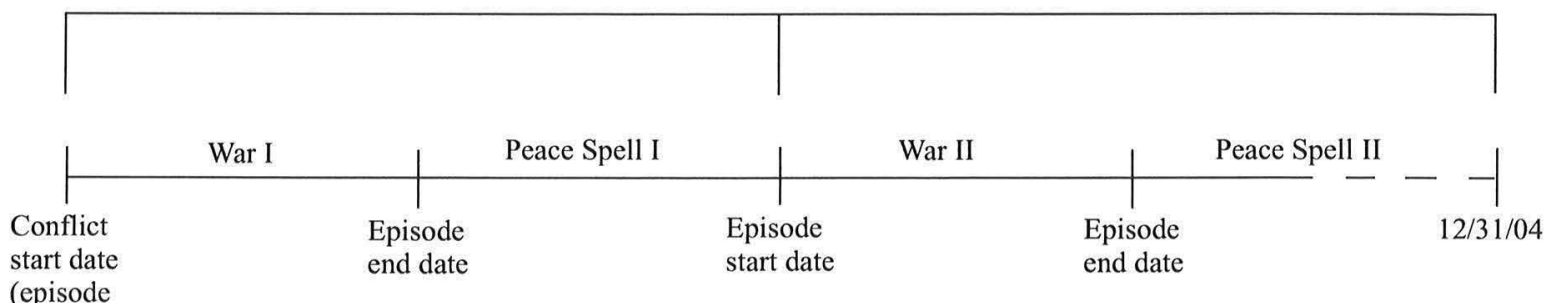

episode

start date)

Figure 1. Coding the mediation cases

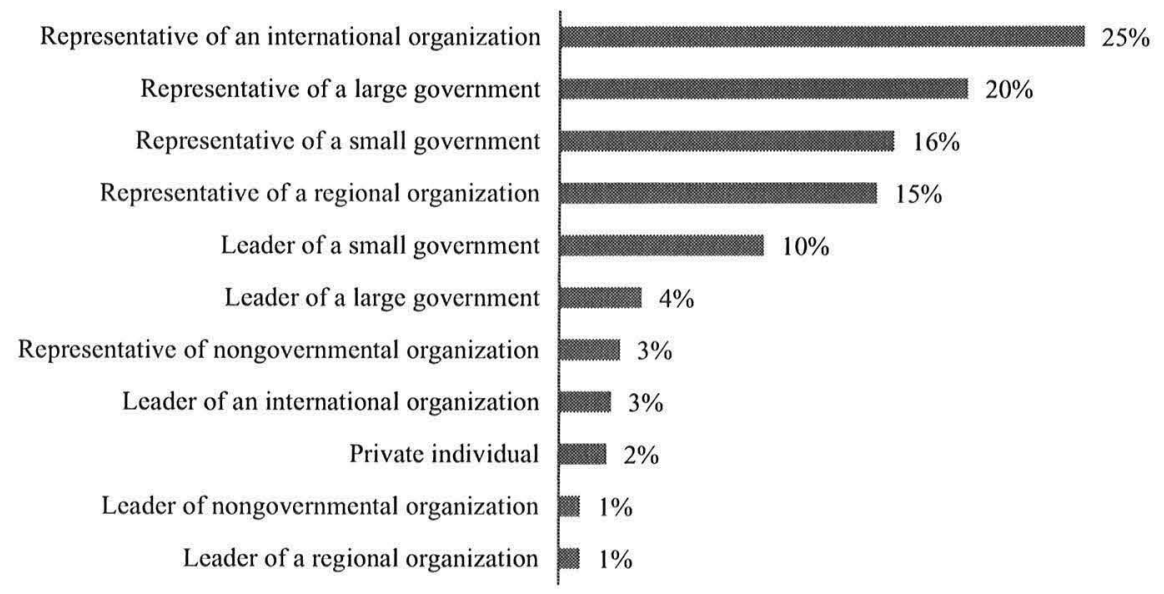

Figure 2. Mediator frequency by rank, 1946-2004 


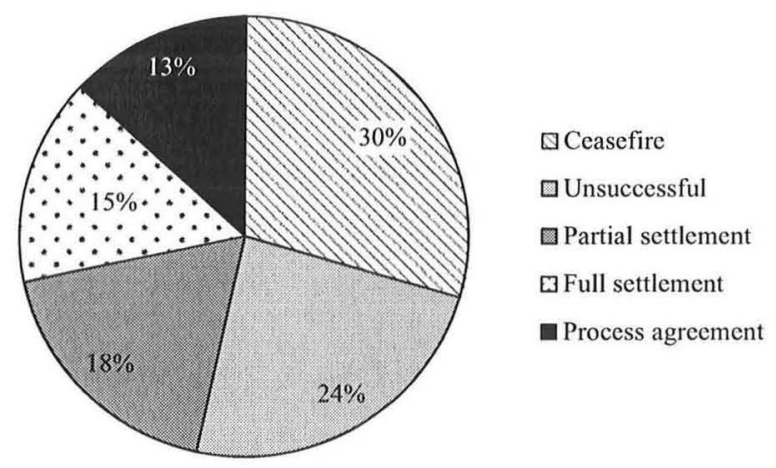

Figure 3. Outcome of mediation efforts, 1946-2004.

channeling information to the parties (Communicative/ Facilitative) or bringing both parties together with some control over the conflict management process and logistics (Procedural). In the latter case, the mediator can, for example, influence timing, agenda-setting, meeting location, and publicity. Since mediators usually employ a mix of different strategies during the course of their engagement in mediation, the CWM dataset also identifies secondary strategies. Strategy is coded based on which method was deemed predominant.

\section{Mediation outcome}

Mediation efficacy cannot be adequately judged by a simple dichotomous measure of whether an agreement is achieved (see Touval \& Zartman, 1985). The CWM data provide information on mediation outcomes. As indicated in Figure 3, mediation was unsuccessful in about $24 \%$ of all efforts. Mediation was associated with positive outcomes - as measured by some sort of agreement - in most cases. Of course, an agreement does not guarantee the episode will not recur.

The CWM data address the longer-term effects of mediation (see Beardsley, 2008; Clayton, 2010) with two variables describing the outcome of mediated disputes two years and five years after the onset of mediation. These variables indicate whether mediation events led to further Negotiations, Political Agreement, Conflict Resolution, Made no Difference, No Positive Results, or a Worsening of Affairs.

The signing of political agreements is considered to be a breakthrough because agreements represent an important first step toward the search for a comprehensive resolution of the conflict (for example, the agreement on holding of elections in the ComorosAnjouan conflict). An example of a political agreement that was preceded by mediation is the 1996 Peace Accord between the Philippine government and the Moro National Liberation Front. Mediation can be said to have led to conflict resolution if it generated a comprehensive peace agreement that is more or less irreversible.

\section{The determinants of mediation}

This section includes basic explorations of mediation occurrence using simple probit models and the new CWM data. ${ }^{3}$ Future work will include the many different aspects of mediation described above.

Bercovitch \& Gartner (2006) and Beardsley et al. (2006) report that mediation is more likely in high intensity conflicts. Mediation might work in these complex conflicts by budging intransigent actors away from their positions and by redefining issues (Beardsley et al., 2006). Greig (2005) notes that interstate rivalry disputes are more likely to be mediated when, among other factors, there is a high level of democracy, there have been a number of previous mediations, the rivalry has endured for a long time, and previous disputes were intense.

In building a model of mediation occurrence, it is useful to think in terms of supply and demand factors. Demand-side factors include the costs of the war, type of war, and stratum. Supply-side factors could include the number of democracies in the world (as potential mediators). The capacity of the state experiencing the war could be considered a supply or regime factor (see Crescenzi et al., 2008). ${ }^{4}$

\section{Operationalization: Regime factors}

The observations in this statistical analysis are civil war episodes. The dependent variable is the presence of mediation in the episodes. The right hand-side variables are described below. Unless otherwise specified, data are from Kreutz (2010).

Polity2 (measure of how democratic the regime is): The polity score data are from Marshall \& Jaggers (2002), measured at time of termination and beginning of war episode on a converted 1-21 scale. The Polity 2 variable is used as an indicator of the country's regime type. The effect of democracy is not entirely clear-cut. Democracies are arguably more amenable to peaceful

\footnotetext{
${ }^{3}$ The main CWM dataset uses mediations as the unit of analysis. However, here we use the mediations in a statistical analysis in which the observations are war episodes. We have two datasets: one with 460 mediations and one with 319 civil war episodes that includes a few of the mediation variables.

${ }^{4}$ Future work could consider the capacity of the mediator.
} 
resolution of disputes (see DeRouen \& Goldfinch, 2005; Dixon, 1994; Greig, 2005). Hegre et al. (2001) report that civil war is more likely in intermediate regimes and that there is no difference between autocracies and democracies. Autocratic regimes (e.g. Myanmar) might be less willing to admit that they cannot win the war and also less willing to give up any control of the negotiated settlement process. Regimes on the democratic end of the scale may not feel that outside mediation is necessary and that the necessary institutions and norms are already present. Wallensteen et al. (2009) report that some level of democracy is required before substantive mediation can take place. They suggest that this was why mediation has been able to work in the wars in Aceh, East Timor, and Bougainville but not those in Myanmar. Savun (2009) was surprised to find democracy had a negative impact on the probability of mediation in interstate war. She suggested that this may be because there are few democratic dyads that have disputes or possibly because potential mediators regard actors in a democratic dyad as possessing unusually high levels of resolve.

Of the 85 civil war episodes in which the Polity 2 score was 16 or greater at war's end, only 30 were mediated. Many of the wars in democracies, such as India, Spain, Turkey, Venezuela, Pakistan, and Trinidad and Tobago, were not mediated. Similarly, few cases of mediation took place in countries with Polity2 scores below 8. Only 26 of 138 cases were mediated. Of the wars that took place in countries with a Polity2 score between 8 and 15, 36 of 96 cases were mediated. Mitchell, Kadera \& Crescenzi (2009: 254) write that democratic dyads will only turn to third parties if bilateral efforts come up short, because they may feel capable of handling the situation with existing institutions and diplomatic channels. However, if the bilateral mechanism fails and a third party is used, the chances of success are higher than for non-democratic dyads.

As a robustness check, we also test the models using Vanhanen's (2000) polyarchy data since they represent a different method of deriving measurements. Gleditsch \& Ward (1997) have shown that there are significant differences when comparing some subdimensions of polity data with other aggregate measures. They find that patterns of executive recruitment and the extent and competiveness of political participation are not particularly powerful in determining the degree of democracy.

Life expectancy: Average of male and female life expectancy at birth measured at end of war. Data are from Political Instability Task Force (2004) and the UNDP. This is a proxy for development, state capacity, and rebel opportunity costs. Higher levels of development could signal greater chance for a peace agreement to obtain.
Higher capacity states might be less willing to give up any control of the process as powerful states do not want to incur reputational costs that could lead to loss of prestige (see Gartner, 2010).

\section{Operationalization: Demand factors}

Territorial war: Coded as 1 if the war concerns autonomy or secessionist claims. Fearon (2004) reports on the intractability of territorial wars. His basic argument is summarized below, but for the purpose of explaining mediation outcomes, it is sufficient to speculate here that territorial wars are more likely to be mediated because of their intractable nature.

Battle-related deaths: These costs are measured as both logged average per year and logged total. These data are from Lacina \& Gleditsch (2005). Toft (2009) finds death rate and total deaths have opposite effects on recurrence. Total deaths reduces the probability while the average death rate increases the probability of the war restarting. It is possible that a high rate can be more closely linked to an urgent need for resolution.

Log war duration: This variable is the log of the number of days the war lasted. In general, the costlier the war in terms of death and duration (see Greig, 2005) the more likely it will be mediated.

Stratum: Here we use a number to reflect whether the termination is the first, second, third, etc. termination within the dyad. If a war is a recurrence, the history of the previous events could shape the outcome (DeRouen, Bercovitch \& Wei, 2009). Greig (2005) found a positive though not significant effect of previous war on the likelihood of current mediation. As mediation, like other social processes, is a learning process, there is reason to believe that mediators will be more than reluctant to intervene in a civil war that has recurred once or twice before. However, recurrence also is a reflection of intractability and as such should lead to more mediation. On balance, we expect that repeat wars are less likely to invite new mediations, as mediation has not been successful in previous wars.

Internationalized war: This variable is coded as 1 if another country intervened militarily. On one hand, these wars should be more likely to be mediated because of the complicating nature of third-party military involvement. This involvement provides a context that would draw in mediators. On the other hand, it could make the party on whose behalf the intervention occurs less likely to agree to mediation. During the Cold War, the civil war in Angola was internationalized with the presence of South African and Cuban troops and significant aid 
from the superpowers. Mediation conceivably becomes less likely in such a situation, as actors see their prospects enhanced by the presence of armed foreign allies.

\section{Operationalization: Supply factors}

Global democracy: In order to get at the availability of mediators (i.e. a supply-side measure), we specify a variable that is simply a count of democracies (Polity2 score > 5 ) in the world. This measure is calculated from Marshall \& Jaggers (2002). Democracies are more likely to mediate civil wars (see Regan, Frank \& Aydin, 2009), and the probability of a given war being mediated should increase as the number of democracies increases as these states are more likely to be interested in peace and make the most credible mediators (Mitchell, Kadera \& Crescenzi, 2009). Crescenzi et al. (2008) develop a supply-side theory of mediation based upon the global supply of democracy. A second measure taps the average global polity score and this variable is expected to act as the global count measure.

Post-Cold War: There was widespread expectation that the end of the Cold War would mean that civil wars being waged with superpower backing would be quickly resolved, thus affording greater opportunity for mediation offers and acceptance. Similarly, the end of the Cold War rivalry has arguably meant that the Security Council might be in a better position to advance the cause of mediation.

\section{Findings}

The results from the probit models are reported in Table I. As expected, territorial wars are clearly more likely to be mediated. This is probably due to their intractable nature. Internationalized wars are more likely to be mediated. It appears that the signaling of the severity of the war via internationalization is more important than the potential resistance of disputants to mediation in these wars. It could also be that the intervening state(s) is pushing for mediation. As evidenced by the percentage of scores predicted correctly and the proportionate reduction in error (PRE) scores, the models do a good job of predicting whether a war will be mediated. The PRE score is an indication of how well a model improves upon simply guessing the modal outcome.

The longer the war, the more likely it is to be mediated. Battle deaths (measured both as yearly average and total) are positive but rather weakly significant. These findings are as expected: intractable wars attract mediation. However, repeat wars are increasingly less likely to be mediated. The Stratum variable is negative and significant in each specification.
The effect of polity is not significant. The results for the Vanhanen robustness checks are also not significant. However, regime type seems to play a different type of role. The supply of democracies in the world has a significant impact on mediation. Similarly, the global polity score also has a positive impact on mediation. These findings are consistent with Crescenzi et al. (2008) and Mitchell, Kadera \& Crescenzi (2009). Life expectancy has a negative though insignificant impact on mediation. This may be because life expectancy is an indicator of a strong state that may be less willing to accept mediation. Finally, the end of the Cold War seems to have heralded more mediation efforts.

\section{Conclusion: Contributions of the new data}

This article uses the new CWM dataset to perform one of the first empirical tests of civil war mediation using the 25 battle death criterion. The analysis of the CWM data led to the following stylized facts and directions for further study:

(1) Territorial wars are more likely to be mediated. This is a robust and widely reported finding. Civil wars fought over territory last longer and have shorter durations of peace. They are also more likely to be mediated. These phenomena are linked. When prospects for a durable peace are dim, actors are more willing to enter into mediation. Fearon (2004) points out that when peripheral rebels begin to achieve battlefield success, the government would typically be willing to accept an autonomy deal rather than face a long war it may not be able to win militarily. Rebels will expect the government to renege once conditions again become favorable to the state. Mediation might be tailored to overcome this problem. There are recent successes in this regard: the agreement ending the war between secessionist Bougainville and the government of PNG, the Good Friday Accords in Northern Ireland, and the Helsinki Accord ending the war over Aceh. Each of these was mediated by a third party.

(2) Longer wars are more likely to be mediated. This relates to the previous finding.

(3) High numbers and rates of casualties increase the probability of mediation. This confirms the arguments of Toft (2009) using different data and methods and likely reflects a sense of urgency. Again, these findings are only marginally significant.

(4) The polity of the regime experiencing the war does not seem to play a consistent role in mediation. However, there is evidence of a supply-side effect of democracy as indicated by Crescenzi et al. (2008). Future attention should be 
Table I. Probit models: The determinants of civil war mediation, 1946-2004

\begin{tabular}{|c|c|c|c|c|c|c|}
\hline & (1) & (2) & (3) & (4) & (5) & (6) \\
\hline \multicolumn{7}{|l|}{ Regime } \\
\hline Polity_end & $\begin{array}{c}0.0199 \\
(0.0159)\end{array}$ & & $\begin{array}{c}0.0173 \\
(0.0153)\end{array}$ & & & \\
\hline Polity_start_-1 & & $\begin{array}{c}-0.00537 \\
(0.0155)\end{array}$ & & & & \\
\hline Vanhanen_end & & & & $\begin{array}{c}0.00307 \\
(0.0113)\end{array}$ & & $\begin{array}{c}0.00259 \\
(0.0110)\end{array}$ \\
\hline Vanhanen_start & & & & & $\begin{array}{c}-0.00995 \\
(0.0114)\end{array}$ & \\
\hline Life exp_end & $\begin{array}{c}-0.00807 \\
(0.00893)\end{array}$ & $\begin{array}{c}-0.00736 \\
(0.00919)\end{array}$ & $\begin{array}{r}-0.00480 \\
(0.00856)\end{array}$ & $\begin{array}{c}-0.0109 \\
(0.0106)\end{array}$ & $\begin{array}{c}-0.00340 \\
(0.0105)\end{array}$ & $\begin{array}{r}-0.00722 \\
(0.00981)\end{array}$ \\
\hline \multicolumn{7}{|l|}{ Demand factors } \\
\hline Ln(bdeath rate) & $\begin{array}{c}0.103+ \\
(0.0572)\end{array}$ & & $\begin{array}{r}0.0864^{\mathrm{a}} \\
(0.0572)\end{array}$ & $\begin{array}{r}0.0883^{a} \\
(0.0580)\end{array}$ & & $\begin{array}{c}0.0716 \\
(0.0578)\end{array}$ \\
\hline Ln(bdeath total) & & $\begin{array}{r}0.0898^{\mathrm{a}} \\
(0.0561)\end{array}$ & & & $\begin{array}{c}0.0596 \\
(0.0531)\end{array}$ & \\
\hline Ln(war dur.) & $\begin{array}{c}0.114^{*} \\
(0.0442)\end{array}$ & $\begin{array}{c}0.119^{*} \\
(0.0593)\end{array}$ & $\begin{array}{r}0.135^{* *} \\
(0.0460)\end{array}$ & $\begin{array}{c}0.124^{*} \\
(0.0465)\end{array}$ & $\begin{array}{c}0.124^{*} \\
(0.0609)\end{array}$ & $\begin{array}{c}0.146^{* *} \\
(0.0488)\end{array}$ \\
\hline Territorial war & $\begin{array}{c}0.351+ \\
(0.195)\end{array}$ & $\begin{array}{c}0.371+ \\
(0.196)\end{array}$ & $\begin{array}{c}0.323+ \\
(0.192)\end{array}$ & $\begin{array}{c}0.408^{*} \\
(0.197)\end{array}$ & $\begin{array}{c}0.362+ \\
(0.192)\end{array}$ & $\begin{array}{c}0.355+ \\
(0.193)\end{array}$ \\
\hline Intlzed war & $\begin{array}{c}0.571+ \\
(0.314)\end{array}$ & $\begin{array}{c}0.496+ \\
(0.296)\end{array}$ & $\begin{array}{c}0.575+ \\
(0.313)\end{array}$ & $\begin{array}{c}0.626^{*} \\
(0.302)\end{array}$ & $\begin{array}{c}0.650^{*} \\
(0.299)\end{array}$ & $\begin{array}{c}0.593^{*} \\
(0.301)\end{array}$ \\
\hline Stratum & $\begin{array}{c}-0.394^{* *} \\
(0.101)\end{array}$ & $\begin{array}{c}-0.332^{* *} \\
(0.105)\end{array}$ & $\begin{array}{r}-0.373^{* *} \\
(0.0993)\end{array}$ & $\begin{array}{c}-0.406^{* *} \\
(0.104)\end{array}$ & $\begin{array}{c}-0.363^{* *} \\
(0.104)\end{array}$ & $\begin{array}{c}-0.375^{* *} \\
(0.101)\end{array}$ \\
\hline \multicolumn{7}{|l|}{ Supply factors } \\
\hline World polity av. & & & $\begin{array}{r}0.224^{* *} \\
(0.0517)\end{array}$ & & & $\begin{array}{r}0.262^{* *} \\
(0.0535)\end{array}$ \\
\hline No. of democracies & $\begin{array}{c}0.0223^{* *} \\
(0.00470)\end{array}$ & & & $\begin{array}{c}0.0266 \\
(0.00484)\end{array}$ & & \\
\hline Post-Cold War & & $\begin{array}{c}0.944^{* *} \\
(0.206)\end{array}$ & & & $\begin{array}{l}1.068^{* *} \\
(0.197)\end{array}$ & \\
\hline Constant & $\begin{array}{c}-2.690^{* *} \\
(0.675)\end{array}$ & $\begin{array}{c}-1.840^{* *} \\
(0.638)\end{array}$ & $\begin{array}{r}-1.752^{*} \\
(0.666)\end{array}$ & $\begin{array}{c}-2.613^{* *} \\
(0.703)\end{array}$ & $\begin{array}{c}-1.921^{* *} \\
(0.660)\end{array}$ & $\begin{array}{r}-1.507^{*} \\
(0.683)\end{array}$ \\
\hline $\mathrm{N}$ & 304 & 278 & 304 & 304 & 305 & 304 \\
\hline Wald $\chi^{2}$ & $60.51^{* *}$ & $62.26^{* *}$ & $56.88^{* *}$ & $68.71^{* *}$ & $69.83^{* *}$ & $61.45^{* *}$ \\
\hline$\%$ pred. correctly & 77 & 74 & 76 & 77 & 74 & 76 \\
\hline PRE & .17 & .12 & .14 & .17 & .08 & .15 \\
\hline
\end{tabular}

Dependent variable is presence of mediation during war or subsequent peace spell; robust standard errors in parentheses are clustered on dyad; $+p<.1,{ }^{*} p<.05,{ }^{* *} p<.005$, two-tailed tests; PRE $=$ proportionate reduction in error; ${ }^{\text {a }}$ significant at .10, one-tailed test.

given to the regime type of mediators in order to track work on interstate conflicts.

(5) Mediation becomes less likely with successive wars (stratum variable). There is a real tension between the need for mediation and the complexity and intensity of a war. It seems that the more intense a conflict is and the more rounds of violence it exhibits, the more reluctant are mediators to intervene. This is an interesting area for future research, and it links civil wars to enduring internal rivalries. In an earlier study, DeRouen \& Bercovitch (2008) found that some civil wars display a similar pattern to enduring rivalries in international disputes, that is, the same pair of actors are engaged in serial violence. Our study demonstrated that the first war in an internal rivalry has different temporal dynamics than do wars that do not recur. In other words, rivalry wars lock-in early and this may be why subsequent wars are less likely to be mediated. This seems to contradict the notion and expectation that the more complicated and intractable civil wars are, the more likely they are to be mediated. There is much more to be said about the role and strategies of mediation (see e.g. Beardsley, 2008; Beardsley et al., 2006). Future research will include additional mediator 
variables from the CWM data. For example, we plan to add: multiple mediation, mediator style, mediator rank, and neutral location.

(6) Mediation is much more common the further one gets from the beginning of the sample. Whether this is because of increasing democratization (a supply side factor) and/or the end of the Cold War remains to be seen.

(7) Internationalized wars are more likely to be mediated. This is likely because these wars are more serious and intense.

The findings above suggest where mediation is more likely to happen, but much more work can and should be done on mediation occurrence and success, and our database offers those research opportunities. Do democratically elected leaders welcome mediation more than other leaders? And what of sudden leadership change? How does that affect the chances of mediation? We need to examine the nature of mediators and see what effect different mediators have on the process and outcomes of mediation. We also need to understand more about how mediators choose among different strategies. Are there any patterns of civil wars that invite only a particular kind of mediation, and if so, which are they? We can also compare the effectiveness of mediation with other forms of diplomatic and non-diplomatic interventions in civil wars. Is mediation, as we think, really the best way to deal with civil wars? These are difficult questions, but if we find answers to them, we may be in a position to offer useful advice to would-be mediators.

\section{Replication data}

The dataset, codebook, and do-files for the empirical analysis in this article can be found at http://www.prio.no/jpr/datasets. Users are urged to contact lead author for most recent versions of the datasets.

\section{Acknowledgements}

We appreciate the support and comments of Birger Heldt, Paul Diehl, Pat Regan, and Govinda Clayton and the assistance of Jenna Lea, Young Park, and Pierre DeRouen. Pospieszna would also like to thank the Fritz Thyssen Foundation.

\section{Funding}

This dataset was created with funding from the Folke Bernadotte Academy (FBA) of Sweden. Earlier versions of this article were presented at the 51st Annual Convention of the International Studies Association, New Orleans, LA, 17-20 February 2010, and the FBA Conflict Prevention Working Group Conference, New York, 2010.

\section{References}

Beardsley, Kyle (2008) Agreement without peace? International mediation and time inconsistency problems. American Journal of Political Science 52(4): 723-740.

Beardsley, Kyle (2010) Pain, pressure and political cover: Explaining mediation incidence. Journal of Peace Research 47(4): 1-12.

Beardsley, Kyle; David M Quinn, Bidisha Biswas \& Jonathan Wilkenfeld (2006) Mediation style and crisis outcomes. Journal of Conflict Resolution 50(1): 58-86.

Beber, Bernd (2010) The effect of international mediation on war settlement: An instrumental variables approach. Paper presented at the Bernadotte Academy Conflict Prevention Working Group Meeting, New York University, 15-16 January (http://homepages. nyu.edu/_bb89/files/Beber_MediationIV.pdf).

Bercovitch, Jacob (1999) International Conflict Management 1945-1995: Official Codebook for the International Conflict Management Dataset. Christchurch, New Zealand: University of Canterbury.

Bercovitch, Jacob \& Karl DeRouen (2004) Mediation in internationalized ethnic conflicts: Assessing the determinants of a successful process. Armed Forces and Society 30(2): 147-170.

Bercovitch, Jacob \& Scott Sigmund Gartner (2006) Is there a method in the madness of mediation? Some lessons for mediators from quantitative studies of mediation. International Interactions 32(4): 329-354.

Bercovitch, Jacob; J Theodore Anagnoson \& Donnette L Wille (1991) Some conceptual issues and empirical trends in the study of successful mediation in international relations. Journal of Peace Research 28(1): 7-17.

Clayton, Govinda (2010) Measuring mediation success: A new framework for empirical studies of conflict management. Paper presented at the 51st Annual Convention of the International Studies Association, New Orleans, LA, 17-20 February (http://www. allacademic.com/meta/p413518_index.html).

Crescenzi, Mark; Kelly M Kadera, Sara Mitchell \& Clayton L Thyne (2008) A supply side theory of mediation. Iowa Research Online (http://ir.uiowa.edu/ polisci_pubs/6).

DeRouen, Karl \& Jacob Bercovitch (2008) Enduring internal rivalries: A new framework for the study of civil war. Journal of Peace Research 45(1): 43-62.

DeRouen, Karl \& Shaun Goldfinch (2005) Putting the numbers to work: Implications for conflict prevention. Journal of Peace Research 42(1): 27-45. 
DeRouen, Karl; Jacob Bercovitch \& Jun Wei (2009) Duration of peace and recurring civil wars in Southeast Asia and the Pacific. Civil Wars 11(2): 103-120.

Dixon, William (1994) Democracy and the peaceful settlement of international conflict. American Political Science Review 88(1): 14-32.

Eralp, Pelin; David Quinn, Jonathan Wilkenfeld, Victor Asal \& Michael Brecher (2010) Delivering peace: Options for mediators in African intra-state crises. Paper presented at the Conflict Prevention Working Group Meeting, New York University, 15-16 January.

Fearon, James (2004) Why do some civil wars last so much longer than others? Journal of Peace Research 41(3): 275-301.

Gartner, Scott Sigmund (2010) Signs of trouble: Regional organization mediation and civil war agreement durability. Paper presented at the Bernadotte Academy Conflict Prevention Working Group Meeting, New York University, 15-16 January.

Gartner, Scott Sigmund \& Jacob Bercovitch (2006) Overcoming obstacles to peace: The contributions of mediation to short-lived conflict settlements. International Studies Quarterly 50(4): 319-328.

Gleditsch, Kristian S \& Michael D Ward (1997) Double-take: A reexamination of democracy and autocracy in modern polities. Journal of Conflict Resolution 41(3): 361-383.

Greig, Michael (2005) Stepping into the fray: When do mediators mediate? American Journal of Political Science 49(2): 249-266.

Greig, J Michael \& Paul F Diehl (2006) Softening up: Making conflicts more amenable to diplomacy. International Interactions 32(4): 355-384.

Hegre, Håvard; Tanja Ellingsen, Scott Gates \& Nils Peter Gleditsch (2001) Towards a democratic civil peace? Democracy, political change, and civil war, 1816-1992. American Political Science Review 95(10): 33-48.

Keesing's World News Archives. Various years (www. keesings.com).

Kreutz, Joakim (2010) How and when armed conflicts end: Introducing the UCDP Conflict Termination Dataset. Journal of Peace Research 47(2): 243-250.

Kydd, Andrew (2003). Which side are you on? Bias, credibility, and mediation. American Journal of Political Science 47(4): 597-611.

Lacina, Bethany \& Nils Petter Gleditsch (2005) Monitoring trends in global combat: A new dataset of battle deaths. European Journal of Population 21(2-3): 145-166.
Marshall, Monty G \& Keith Jaggers (2002) Polity IV Project: Political regime characteristics and transitions, 1800-2000 (www.cidcm.umd.edu/inscr/polity/).

Mitchell, Sara; Kelly Kadera \& Mark Crescenzi (2009) Practicing democratic community norms: Third party conflict management and successful attempts. In: Jacob Bercovitch \& Scott Gartner (eds) International Conflict Mediation: New Approaches and Findings. London: Routledge, 243-265.

Political Instability Task Force (2004) Frequently Tested Variables Data Dictionary (http://globalpolicy.gmu.edu/ pitf/Frequently\%20Tested $\% 20$ Variables\%20Data $\% 20$ Dictionary.pdf).

Rauchhaus, Robert (2006). Asymmetric information, mediation and conflict management. World Politics 58(2): 207-241.

Regan, Patrick \& Aysegul Aydin (2006) Diplomacy and other forms of intervention in civil wars. Journal of Conflict Resolution 50(5): 736-756.

Regan, Patrick M \& Allan C Stam (2000) In the nick of time: Conflict management, mediation timing, and the duration of interstate disputes. International Studies Quarterly 44(2): 239-260.

Regan, Patrick; Richard W Frank \& Aysegul Aydin (2009) Diplomatic interventions and civil war: A new dataset. Journal of Peace Research 46(1): 135-146.

Savun, Burcu (2009) Mediator type and effectiveness of information-provision strategies in the resolution of international conflict. In: Jacob Bercovitch \& Scott Gartner (eds) International Conflict Mediation: New Approaches and Findings. London: Routledge, 96-115.

Smith, Alastair \& Allan Stam (2003) Mediation and peacekeeping in a random walk model of civil and interstate war. International Studies Review 5(4): 115-135.

Svensson, Isak (2007) Bargaining, bias and peace brokers: How rebels commit to peace. Journal of Peace Research 44(2): 177-194.

Toft, Monica Duffy (2009) Securing the Peace: The Durable Settlement of Civil Wars. Princeton, NJ: Princeton University Press.

Touval, Saadia \& I William Zartman (1985) Introduction: Mediation in theory. In: Saadia Touval \& I William Zartman (eds) International Mediation in Theory and Practice. Boulder, CO: Westview, 7-18.

Vanhanen, Tatu (2000) A new dataset for measuring democracy, 1810-1998. Journal of Peace Research 37(2): 251-265.

Wallensteen, Peter; Karl DeRouen Jr, Jacob Bercovitch \& Frida Möller (2009) Democracy and mediation in territorial civil wars in Southeast Asia and the South Pacific. Asia Europe Journal 7(2): 241-264. 
Walter, Barbara (2002) Committing to Peace: The Successful Settlement of Civil Wars. Princeton, NJ: Princeton University Press.

Wilkenfeld, Jonathan; Kathleen Young, Victor Asal \& David Quinn (2003) Mediating international crises: Cross-national and experimental perspectives. Journal of Conflict Resolution 47(3): 279-301.

Wilkenfeld, Jonathan; Kathleen J Young, David M Quinn \& Victor Asal (2005) Mediating International Crises. New York: Routledge.

KARL DEROUEN JR, b. 1962, PhD in political science (Texas A\&M University, 1993); Professor, The University of Alabama (2007-); research interests: civil wars and international political economy. Recent books: Understanding Foreign Policy Decision Making, with Alex Mintz (Cambridge University Press, 2010); Unravelling Internal Conflicts in East Asia and the Pacific, co-edited with Jacob Bercovitch (Lexington Press, 2011).
JACOB BERCOVITCH, b. 1951, PhD in political science (London School of Economics, 1980); Professor, School of Political Science and Communication, University of Canterbury (1996-2011); research interests: international mediation, conflict resolution, and international negotiation. Published extensively on the theory of mediation and mediation effectiveness, including Unravelling Internal Conflicts in East Asia and the Pacific, co-edited with Karl DeRouen Jr (Lexington Press, 2011).

PAULINA M POSPIESZNA, b. 1978, PhD in political science (University of Alabama, 2010); post-doctoral researcher at the University of Konstanz (2010-); research interests: third-party mediation in internal conflicts, democracy assistance, regional diffusion of democracy, the impact of international and non-governmental organizations on democratization and post-conflict reconstruction, state-civil society relations. 